\title{
International Experience Of Ranking Of Georgian Business Environment And Its Impact On Economic Activity
}

\author{
George Abuselidz \\ Doctor of Economics, Professor at Shota Rustaveli State University, Georgia \\ Giorgi Katamadze \\ PhD student, Shota Rustaveli State University, Georgia
}

\begin{abstract}
The process of radical economic and political transformations in modern Georgia, establishment of a new economic system and assurance of its effectiveness demands maintenance of macroeconomic ratios, improvement of business environment and supporting of economic activity in general. Many factors impact the activity of business subjects and their successful business environment. Such factors are incomes of entities, strong business competitions, production and realization of specific goods, production specifics of the spheres, social and political situation of the given country, as well as the incomes of the different social strata and their economic situation. The present article is focused on adequacy of evaluation of business climate and the directions of its perfection, having the vital importance for increasing of business activity.
\end{abstract}

Keywords: business environment, economic activity, business subjects

\section{INTRODUCTION}

Active business entities and successful business climate are regarded as the most important and integral part of economic strength and stability of the country. Therefore proper operation of different mechanisms which facilitate and support the process of doing business, have essential and prior importance for the given country.

In general the business entities and the results of their business activity form the part of economy, at the same time they play an important role in the process of formation of the budget - the main financial document since the budgetary tax return is mainly depended on the results of company activity and vice-versa.

Therefore it is important the fiscal policy to stimulate economic activity and increase the production through increase of budgetary income and vice-versa, the development of economic activity and increase of production volume to ensure the increase of budgetary income (Abuselidze, 2012)

Activity of business entity depends on variety of factors, the most important among them is favorable economic environment which includes positive image of the country on international level, stable political situation, conducive regulatory environment, state programs oriented on business development and proper work of state institutions.

Company's success is directly connected to its adaptation to the existing business climate. Since it is dynamic under the influence of different factors the company's - its management's 
main aim is to focus on ongoing processes in the country and adequate reflection/adaptation of any changes in the company activity.

The business environment is created independently from the business entities. A standingalone company cannot affect or change it. Thus the business climate directly impacts the companies' activity. The business climate should be focused on business subjects, and the business subjects should be focused on customers.

It should be noted that business environment includes cooperation of customers and state institutions, representing the key issue to the successful business activity. Companies' activity can be influenced by the customers and government, therefore the companies should meet the existing requirements and demands in order to get income, pay taxes, salaries, provide favorable working environment and keep up with the ongoing processes.

\section{The article aims to analyze:}

- the current ranking of Georgia according to the researches carried out by the international organizations;

- the criteria of evaluation;

- business activity of the business subject registered in Georgia and define the current business trends.

Research methods. Several methods - as quantitative as qualitative, have been combined in the process of preparation of the present article.

\section{LITERATURE REVIEW}

The present article is based on the official data of Ministry of economy and sustainable development of Georgia, Ministry of finance of Georgia, National statistics office of Georgia, National agency of public registry of Georgia, The World Bank and etc.

In the process of writing of the article we have absorbed the scholarly articles by A. Smith, B. Milner, W. Fogel, Douglass C. North and other authors regarding business environment and general business processes, economic situation, the working strategies of the entities and etc.

\section{RESEARCH}

In line with the different criteria of the international evaluation index, many research methods makes it possible to gather comprehensive data on those countries with positive business climate, and to identify the existing business and economic problems and obstacles.

The World Bank Group project The Doing Business launched in 2002 annually provides economic and business analysis in 189 countries, preparing the report on ease of doing business ranking; according to the report Georgia holds $24^{\text {th }}$ position among the countries for 2016. ${ }^{1}$ [11]

- In particular: the $6^{\text {th }}$ position according to the starting a business, according to dealing with construction permits $-11^{\text {th }}$ position, getting electricity $-62^{\text {th }}$ position, registering property $-3^{\text {th }}$ position, getting credit $-7^{\text {th }}$ position, protecting minority investors $-20^{\text {th }}$ position, paying taxes $-40^{\text {th }}$ position, trading across borders $-78^{\text {th }}$ position, enforcing contracts $-13^{\text {th }}$ position and resolving insolvency $-101^{\text {th }}$ position. 
The Doing Business evaluation criteria are:

1) Starting a business ${ }^{2}[12]$ - includes analysis of all procedures and regulatory base required for a business to be started. If there is more than one type of limited liability Company in the economy, the limited liability form most common among domestic firms is chosen. In the process of registration only those stages are considered that are common and required for all business subjects.

2) Dealing with construction permits -includes the analysis of all procedures required for a company in the construction industry to build a building along with the time and cost. In addition, it includes the building quality control index - the quality control and safety mechanisms, liability and insurance regimes, and professional certification requirements.

3) Getting electricity - records all procedures required for a business to obtain a permanent electricity connection and supply. These procedures include applications and contracts with electricity utilities, all necessary inspections and clearances from the distribution utility and other agencies, and the external and final connection works. This criteria includes three aspects: electricity supply, transparency of tariffs, simplicity of electricity supply and its reliability.

4) Registering property includes the full sequence of procedures necessary for a business (the buyer) to purchase a property from another business (the seller), as well as all the transactions connected to any operations carried out in towards the property.

5) Getting credit - includes measuring of the legal rights of borrowers and lenders, credit terms and credit accessibility, exchange of credit information in credit database and its accessibility.

6) Protecting minority investors measures the protection of minority investors from conflicts, legal standards of rights and interest protection on the county and etc.

7) Paying taxes records the taxes and mandatory contributions that a medium-size company must pay in a given year as well as the administrative burden of paying taxes and contributions. It separately measures the profit tax, dividend tax, property taxes, income taxes and other taxes.

8) Trading across borders records the time and cost associated with the logistical process of exporting and importing goods.

9) Enforcing contracts measures the time and cost for resolving a commercial dispute through a local first-instance court. As well as the quality of judicial processes index.

10) Resolving insolvency analysis the time, cost and outcome of insolvency proceedings, as well as the strength of the legal framework applicable to liquidation and reorganization proceedings.

According to the abovementioned criteria, Georgia holds its leading positions ${ }^{3}$ [13]among such countries as Poland, Switzerland, France, Holland, Slovakia, Slovenia, United Arab Emirates and others. 
In order to depict the whole picture of each problem, the research process shall be based on the real, practical examples and experiences. Such problems may vary in the companies.

The international evaluation is of a great importance for the economic situation of the country, since it is an initial data on economic environment and it is accessible. This record probably serve as an indicator for an investor before investing into a country.

It is also very interesting and important to evaluate the corruption perception index in the process of economic environment analysis.

Corruption perceptions index includes the total volume of international corruption (frequency and/or volume of corruptive transactions) as in political, as in social sectors and makes ranking of the countries according to the corruption perception. In this category, Georgia holds its $48^{\text {th }}$ position ${ }^{4}$ [14] and has 52 points. It is notable that in this ranking the countries like Italy, Hungary, Croatia, Romania, Bulgaria, Turkey, Brazil, China and others follow Georgia.

According to the political and industrial evaluations Georgia maintains its stable positions and meets the following requirements of the international financial institutions ${ }^{5}[14]$ (WB, ADB, ETC)

- Standard \& Poor's: BB- Stable

- Moody's: Ba3 Stable

- Fitch Ranking: BB- Stable

Effective communication between the business and government (a governmental structure) is one of the most important conditions for prosperous business. Since the process of business registration and management is facilitated and free of bureaucratic mechanisms it seems that business activity should be versatile, successful, and profitable and the business entities should be active.

The official data of the National agency of public registry ${ }^{6}$ [10] on registration of business entities for the recent years are as follows:

Table N1 ${ }^{7}[10]$

\begin{tabular}{|l|l|l|l|}
\hline Year & Registered business entity & LTD & Ind. entrepreneur \\
\hline 2010 & 47.014 & 11.213 & 34.789 \\
\hline 2011 & 54.081 & 14.011 & 38.632 \\
\hline 2012 & 43.934 & 14.943 & 27.624 \\
\hline 2013 & 47.792 & 17.701 & 28.157 \\
\hline 2014 & 47.600 & 17.553 & 27.778 \\
\hline 2015 & 45.800 & 18.416 & 24.808 \\
\hline $2016 / 03$ & 11.952 & 5.151 & 5.979 \\
\hline
\end{tabular}

2011 is the most active year with 54,081 registered companies. It should be noted that political processes also impacts the business activity, in particular a new economic policy, investors' cautious attitude towards the new political atmosphere and other. This fact has reflected in 
Georgian reality and the number of registered businesses considerably decreased in comparison to the number of registrations for 2011 year.

Thus, it should be mentioned that no changes have been occurred in Georgia reflected in the international evaluation rankings. ${ }^{8}[11]$

Business activity data for the first quarter of 2016 is as follows: ${ }^{9}$ [9]

Table N2 ${ }^{10}$

\begin{tabular}{|c|c|c|c|}
\hline Type of business activity & $\begin{array}{l}\text { Number } \quad \text { of } \\
\text { entities }\end{array}$ & Active & $\%$ \\
\hline Total & 626029 & 130465 & 100 \\
\hline Agriculture, hunting and forestry & 5453 & 1171 & 0.9 \\
\hline Fishing & 365 & 118 & 0.1 \\
\hline Mining industry & 1281 & 550 & 0.2 \\
\hline Processing industry & 28639 & 9882 & 4.6 \\
\hline Electricity, gas and water output and supply & 492 & 151 & 0.1 \\
\hline Construction & 14771 & 5772 & 2.4 \\
\hline $\begin{array}{l}\text { Trade, cars, housewares and private consumption items } \\
\text { repair }\end{array}$ & 126286 & 55579 & 20.2 \\
\hline Hotels and Restaurants & 11209 & 4766 & 1.8 \\
\hline Transportation and communication & 17148 & 6512 & 2.7 \\
\hline Financial activity & 3370 & 1691 & 0.5 \\
\hline Real estate transactions, lease and customer service & 24134 & 11145 & 3.9 \\
\hline State entities & 1800 & 405 & 0.3 \\
\hline Education & 6436 & 3975 & 1.0 \\
\hline Healthcare and social services & 5347 & 2840 & 0.9 \\
\hline Public service, social and personal services & 18887 & 3728 & 3.0 \\
\hline Non-identified activity & 360411 & 22180 & 57.0 \\
\hline
\end{tabular}

Total number of registered entities is 626029 and 412680 entities (65.9\% of the total number) among them have the status of individual entrepreneur and 6228 are the entities of public law (1\%).

Conspicuous is the fact that only 130465 entities out of 626029 registered entities is active for the given moment that makes $20,8 \%$ of all registered companies. It is also considerable that 360411 business entities carry out non-identified business activity, that is $57,5 \%$ of the total number of entities and only 22180 entity or $6.15 \%$ is active. 
It's the fact that development of any country depends on some aspects and the economic situation is the most important among them; business entities - being the institutional elements of business activity, make the basis of strong economic situation.

The economic activity has a direct effect on business activity; high business activity impacts employment level; employed population improves the social background of the country, infrastructure and all these support a stable development of the country. Development of business and its protection in critical situations, proper, continuous and protected activity becomes more and more important for entrepreneurs and the state. European countries pay special attention to development of business sphere and the country development strategy mostly depends on business strengthening in recent years. The successful business provides strengthening and economic stability of the population and is the main basis of developed country.

In fact, most part of the registered companies terminate or suspend their activities soon after their registration. In many cases the company suspends its activity or is liquidated under the management decision (there are many reasons for doing so - alteration of business sphere, turnover differentiation, business separation and etc.) but in general the main reason of doing so is that companies are unable to overcome the problems and control the existing crisis.

In critical situations the prompt reaction is the key issue. The crisis isn't always followed by dissolution of the company, in some cases the insolvent company can be merged or rebranded into other company. Some researchers (Greiner 1972:56-80, Dr. Ichak Adizes 2004 and others) distinguish variety of reasons causing the crisis, but it should be noted that most of them can be divided into two groups: exogenous and internal factors.

The exogenous factors are independent one, which cannot be controlled by the company, for example the political-economic situation in the country, force majeure, business competition, functional depreciation of goods and services and others.

While the internal factors are: management problem, employees' low level of competence, poor quality of goods-services rendered and others. Generally, the exogenous and internal factors are interrelated, since the one of them can affect another one and vice-versa.

According to Adam Smith ${ }^{11}$ [7] besides the natural and affected factors, there are one more factor - the government, which also can affect business activity by interference into the business process by prices adjustment. Adam Smith distinguishes the role of government to be a separate mechanism out of the group of state regulations or politics.

According to Robert W. Fogel, Douglass C. North ${ }^{12}$ [6]: "Efficient markets are created in the real world when competition is strong enough via arbitrage and efficient information feedback to approximate the Coase zero transaction cost conditions and the parties can realize the gains from trade inherent in the neo-classical argument..... Competition also plays a critical role in reducing enforcement costs. The judicial system provides coercive enforcement. Still, economic markets in the past and present are typically imperfect and beset by high transaction costs." (North, Fogel 1993:5).” 
Some authors such a David W. Conklin ${ }^{13}[4]$ "Economic forces differ among nations and continually change over time. Analyses of their likely impacts and the creation of appropriate economic strategies can be the central determinant of a firm's success. The attractiveness of a particular market depends on its industry structure, including the competitiveness of existing firms, the threat of substitutes and new entrants, and the bargaining power of suppliers and customers. New communication technologies have facilitated international outsourcing, enabling each firm to locate each activity in whatever country offers the optimal combination of cost, quality, and other attributes. New organizational structures may be required to coordinate international networks and to stimulate international innovation."

\section{CONCLUSIONS}

As we see from the international rankings evaluations of Georgia in Doing Business category is very positive. It should be noted that the corruption index is also very positive. All these causes the following questions:

- If the business environment is conducive and positive, why is the most part of registered companies passive?

- What is the main reason of company stagnation?

Basing on the abovementioned, there might be several reasons for the companies to be passive, among them:

- The registration process is too easy and it is possible to register a business even on a one-off basis;

- Non-resident companies take part in state tenders/programs which mostly carry out one-off operations;

- Company cancellation and liquidation process is too long;

- In case of termination of its activity the companies may have the status "activity suspended" and it doesn't mean cancellation or termination of registration;

- Registered companies doesn't have the obligation of having a year turnover.

According to our survey conducted among some companies, there are some reasons causing the trouble to the active companies, among them: changeable exchange rates, high interes rates on credits, unequal business competition, informal institutions, unstable political orientation and others.

Taking into consideration the abovementioned reasons, we think in order to analyze this sphere it is necessary to study the following issues: the economic policy focused on business support, legal and institutional changes, governmental decision aiming business support.

Thus, in order the business environment evaluation in Georgia to be adequate and perfect, it is necessary to study not only the stages of business registration and cancellation (so called start and liquidation processes) but also the existing problems in the process of business activity, which detains the company and leads to critical situations and finally to the liquidation/reorganization. We think it would be the very analysis, serving as the basis for evaluation of business activity. 


\section{References}

Abuselidze, G. (2013). Optimal Tax Policy-Financial Crisis Overcoming Factor. Asian Economic and Financial Review, 3(11), 1451-1459.

Abuselidze, G. (2012). The influence of optimal tax burden on economic activity and production capacity. Intelektine Ekonomika, 6(4).

Adizes, I. K. (2004). The ideal executive. Why you cannot be one and what to do about it. A new paradigm for management. The Adizes institute publishing. CA.

Conklin, D. W. (2011). The Global Environment of Business: New Paradigms for International Management, Sage Publications, Thousand Oaks California.

Greiner L. E. (1972). Evolution and Revolution as Organizations Grow", Vol. 50(4). President and Fellows of V.

Robert W. Fogel, Douglass C. North, (1993). Economic Performance through Time, Lecture to the memory of Alfred Nobel.

Smith, A. (1938). An Inquiry into the Nature and Causes of the Wealth of Nations.

The Association of Young Economists of Georgia, Civic Education Section, Improving business opportunities and challenges of the business environment in Georgia (the survey) studies in economics: the National Library of Georgia, 2008. http://www.nplg.gov.ge/gsdl/cgi-bin/library.exe

National Statistics Office of Georgia, List of active businesses by activity http://geostat.ge/?action=page\&p_id=229\&lang=geo

National Public Registry Agency of Georgia, business registration stages according to the legal status, https://napr.gov.ge/p/227

Economy rankings by doing business, http://www.doingbusiness.org/rankings

methodologies for each Doing Business topic and to the Doing Business 2016 questionnaire instruments, http://www.doingbusiness.org/methodology

Measuring Business Regulations http://www.doingbusiness.org/data/exploreeconomies/georgia/

Transparency International Corruption perceptions index 2015, http://www.transparency.org/cpi2015

Ministry of economy and sustainable development of Georgia, Georgia in International Ratings, http://www.economy.ge/ge/economic-data/rankings-of-georgia

Ministry of Finance of Georgia, General Government Operations, http://mof.gov.ge

Мильнер Б.З., Теория организации, ИНФРА-М, Москва, 2000 